\title{
Timeline of the Key Events of War and Aftermath, 1991-2003
}

1991

March Foday Sankoh and the Revolutionary United Front (RUF) invade Sierra Leone from Liberia. For the next several years, the war remains confined to the southern and eastern regions.

1992

April

President Joseph Momoh (APC) is ousted in a coup of junior army officers; Captain Valentine Strasser is later announced as the head of the National Provisional Ruling Council (NPRC).

1996

January

Maada Bio seizes command of the NPRC in a bloodless coup.

March Tejan Kabbah wins a democratic election. His Sierra Leone People's Party (SLPP) takes power and Deputy Minister of Defense Sam Hinga Norman moves the civil militias into an official role fighting the RUF alongside the army. 
November The first peace agreement, the Abidjan Accords, is negotiated between the government and the RUF.

1997

May

Combined RUF and army elements march into Freetown and overthrow Tejan Kabbah's government. Kabbah and his cabinet flee to Guinea. The Armed Forces Revolutionary Council (AFRC), with Major Johnny Paul Koroma at its head, seizes control of the country. Combined rebel and mutinous army forces deploy throughout the country. Kabbah, from exile, announces the disbanding of the army.

1998

February

Troops from the Economic Community of West African States (ECOWAS) seize the capital city Freetown from the AFRC after fierce fighting. The AFRC flee up the highway into the bush northeast of Makeni.

April Kabbah appoints Nigerian General Maxwell Khobe head of the armed forces; Nigerian troops deploy throughout the country.

December Combined forces of the RUF and former AFRC members invade Makeni from the countryside and forcibly occupy the town, chasing Nigerian troops to Mile 9I.

1999

January The combined forces of the RUF and former AFRC members who bypassed Makeni march to Freetown, overwhelming ECOWAS forces. Thousands are killed as ECOWAS and the new Sierra Leonean army regroup to push the rebels out.

January-May Various factions of the RUF and former AFRC fight for control of Makeni, a conflict known locally as the infights. General Issa Sesay of the RUF emerges the winner. 
July

2000

January

May

June

June-October

November
Foday Sankoh and Tejan Kabbah officially sign the Lomé Peace Accords, ending the war, giving blanket amnesty to RUF fighters, and establishing the existence of the United Nations Assistance Mission to Sierra Leone (UNAMSIL).

UNAMSIL begins construction on combatant disarmament centers, one of which is built in Makeni.

RUF troops attack the Makeni disarmament center, killing fifty peacekeepers.

Tejan Kabbah announces that because Makeni is home to only "rebels and rebel collaborators," he will use the army's gunship to bomb the town.

Gunship attacks on Makeni spark a mass exodus from the town.

The government and the RUF sign a ceasefire agreement in Abuja.

2001

May

The National Commission for Disarmament, Demobilization, and Reintegration (NCDDR) establishes an office and new disarmament center in Makeni.

2002

May

Issa Sesay loses his campaign for a seat in parliament in national elections, which also return Tejan Kabbah to the presidency. Sesay dismantles all official RUF offices in Makeni and claims an end to the RUF in Makeni.

2003

March The new Special Court for Sierra Leone indicts Charles Taylor, Foday Sankoh, Issay Sesay, and nine others on charges of war crimes. 
2012

May

The Hague's Special Court for Sierra Leone convicts Charles Taylor of eleven counts of aiding and abetting the RUF, including planning the Makeni invasion. Taylor is sentenced to fifty years in prison for war crimes that include supplying and encouraging rebels in Sierra Leone in a campaign of terror, involving murder, rape, sexual slavery, and the conscription of children under the age of fifteen. 